\title{
Increasing Visibility of the Turkish Fans of South Korean Popular Culture through Translation
}

\author{
Güney Kore Popüler Kültürünün Türkiye'deki Fanlarının Çeviri Yoluyla Artan \\ Görünürlüğü
}

Research/Araştırma

\section{Mehmet ERGUVAN}

Assist. Prof. Dr., Beykent University, Faculty of Arts and Science, Department of Translation and Interpreting, m.erguvann@gmail.com, ORCID ID:0000-0003-3649-8392

\begin{abstract}
Having made a remarkable contribution to social questions in translation studies, the sociological approach to translation explores the interaction between human agents, translated texts, and their context of production and reception (Chesterman, 2006; Wolf \& Fukari, 2007; Wolf, 2011). The research in this study is focused on target text users/pro-consumers. In line with this aim, this study is centered on Turkish fans of South Korean popular culture, most of whom have consumed, produced, and distributed diverse Korean popular culture products largely through translation. The present research particularly intends to problematize Korean fandom in Turkey considering John Fiske's approach to fandom, which is based on Bourdieu's consideration of culture, operating like an economic system to distribute its resources unequally and therefore distinguishing between individuals who possess greater degree of capital and the others deprived of it. This research, based on the Internet-mediated interviews (with 43 Turkish fans of South Korean pop culture), argues that Bourdieu's consideration of fans as a group that is devoid of social and cultural power and is considered undistinguished in their cultural preferences and interpretative practices partly fails to enlighten the case of the Korean Wave fans in Turkey. This study has revealed that, cultural capital is not fixed but open to struggles, disclosing the fact that accumulation of popular cultural capital can bring prestige to certain fans that are more involved in and possess high knowledge within the fan community. Then, it has been posited that social networks play a far more major role in the formation and persistence of the fan community than does the accumulation of cultural capital. It has also been observed that popular cultural capital of Korean Wave fans can readily be converted into high social capital since Turkish fans who display their accumulated popular cultural capital are able to broaden their reach to other fans. Lastly, this research discloses that, Turkish fans' increasing visibility and their influence over mass
\end{abstract}


culture appear to form a particular kind of fan habitus which allows for variability in tastes and actions of the fans.

Key words: Korean Wave, Korean popular culture fandom in Turkey, popular cultural capital, social capital, fan habitus.

\section{ÖZET}

Çeviribilim alanındaki toplumsal soru(n)ların irdelenmesine kayda değer katkılar sunan sosyolojik yaklaşımlar, insan unsuru, çeviri metinler, ayrıca çevirilerin üretim ve alımlanma süreçleri arasındaki etkileşimi incelemektedir (Chesterman, 2006; Wolf \& Fukari, 2007; Wolf, 2011). Bu çalışma, söz konusu parametrelerden hedef metin alıcılarını/üre-tüketicileri sorunsallaştırır. Bu bağlamda, çalışma boyunca Kore popüler kültürüne ait çeşitli ürünleri çoğu zaman çeviri yoluyla tüketen, üreten ve yayan bir kitle, bir diğer deyişle, Güney Kore popüler kültürünün Türkiye'deki fanları odak noktası olacaktır. Söz konusu araştırma bilhassa Türkiye'deki Kore hayranlığını John Fiske'in fan kültürüne ilişkin yaklaşımı çerçevesinde sorunsallaştırmayı hedefler. Fiske'nin yaklaşımı, Bourdieu tarafından ortaya atılan, kaynakların eşit dağıtılmadığı ve bu nedenle daha fazla sermayeye sahip bireylerle bundan yoksun olanlar arasında ayrımın hasıl olduğu ekonomik sistem gibi işleyen kültür anlayışına dayanmaktadır. İnternet üzerinden gerçekleştirilen röportajlara (Güney Kore popüler kültürü fanı olan 43 kişiyle) dayanan bu araştırma, Bourdieu'nun fanları sosyal ve kültürel güçten yoksun, ayrıca kültürel tercihleri ve yorumlayıcı pratikleri açısından homojen bir grup şeklinde yorumlamasının Türkiye'deki Kore Dalgası fanlarının durumunu aydınlatmak açısından kısmen eksik kaldığını ileri sürer. Bu çalışma, kültürel sermayenin sabit olmadığını, bilakis mücadeleye açık olduğunu öne sürmüş ve popüler kültürel sermaye birikiminin, fan topluluğuna daha fazla dahil olan ve daha çok bilgiye sahip bazı fanlara prestij kazandırabileceğini ortaya koymuştur. Hemen akabinde, kültürel sermaye birikimine kıyasla sosyal ağların fan topluluğunun oluşumunda ve kalıcılığında çok daha önemli bir rol oynadığı ortaya çıkmıştır. Ayrıca Kore Dalgası fanlarının popüler kültürel sermayesinin, birikmiş popüler kültürel sermayelerini sergileyen fanların diğer fanlara erişimini genişletebildiği için kolaylıkla yüksek sosyal sermayeye dönüştürülebildiği gözlemlenmiştir. Son olarak, bu araştırma, Türkiye'deki fanların artan görünürlüğünün ve kitle kültürü üzerindeki etkilerinin, sahip oldukları zevkler ve eylemler açısından çeşitlilik gösteren belirli bir fan habitusu oluşturduğunu ortaya koymaktadır.

Anahtar Kelimeler: Kore Dalgası, Türkiye'de Kore popüler kültürü hayranlığı, popüler kültürel sermaye, sosyal sermaye, fan habitusu.

\section{Introduction}

The term Korean Wave, or Hallyu was coined by the Chinese press to refer to the growing popularity of Korean popular culture driven by the spread of various culture products including K-dramas, songs, movies and so on (Binark, 2019, p. 17). Korean popular culture has more recently started evolving from its comfort zone in Asia, and it has created a strong preference for its culture products particularly in the Middle East, Europe, and the USA. In the last decade, it also prevailed in Turkey mainly through translation activities of an increasing number of fans, or, as Duraner, Işıklar-Koçak and Tunalı refer to them, "self-appointed and voluntary cultural agents" (2017, p. 146). In this light, this part of the study will discuss how enjoyment of Korean dramas in Turkey has led to a growing interest in pop music and movies on the one hand, and, on the 
other, Korean fashion, and Korean lifestyles. To enlighten the extension ${ }^{1}$ of Korean cultural products, which initiated further cultural production in Turkey, this paper employs Itamar Even-Zohar's concepts of culture repertoire, importation, and option, which conceptualize these products as cultural products introduced into the Turkish culture repertoire and imported as options for Turkish consumers (Even-Zohar, 2002). The idea of cultural repertoire ${ }^{2}$ refers to "the aggregate of options utilized by a group of people, and by individual members of the group, for the organization of life" $(2002, p$. 166). It can steer the making, handing, production and/or consumption of any given product (Even-Zohar, 1997). This section takes fans ${ }^{3}$, "the most visible and identifiable of audiences" (Lewis, 1992, p. 1), as a point of departure, and examines Korean popular culture fans in Turkey as self-appointed agents who introduce Korean cultural content into the Turkish cultural repertoire as new options, and hence present "alternative, different and new models of life" (Even-Zohar, 2005, p. 198). This is because, following "the shift from an electronic media to a digital media culture", these self-appointed agents, who usually take on the role of translation commissioners and selectively appropriate the audiovisual content they want to subtitle and/or distribute, play a considerably broader role within the participatory media industries (Pérez-González, 2012, p. 158). Therefore, it is possible to argue that the contribution of amateur translators and other self-appointed agents to the circulation of media content in the era of digital culture is explicit and the implications of their practices for the consolidation of digital culture deserve serious consideration.

Introduction of Korean dramas as options for Turkish consumers started the influx of Korean popular culture in Turkey. Following the agreement between the Korean television channel Arirang TV and TRT (Turkish television channel), a set of Korean dramas were aired in Turkey in 2005 (Oh \& Chae, 2013). The first Korean drama broadcast in Turkey was Emperor of the Sea, which was followed by All In, a hit program in Korea in 2003. Then, fansubbers among the Korean popular culture fans in Turkey began to subtitle other Korean dramas into Turkish. They continue their fansubbing activities in subtitle sharing websites (e.g. Divxplanet) and other Korean popular culture

\footnotetext{
${ }^{1}$ In this study, the term "extension" refers to media producers' efforts "to expand the potential markets by moving content across delivery systems" (Jenkins, 2006a, p. 19). That is, it defines the process how one product extends outward from its originating medium to involve in other sites of cultural production.

${ }^{2}$ Cultural repertoire tends to "introduce new options through invention or importation, whether intentional or unintentional, by anonymous contributors or known members of the society" (Even-Zohar, 2002, p. 168). Even-Zohar calls these named or unnamed individuals who conduct the presentation and integration of options as agents of transfer.

${ }^{3}$ Fans' steadily growing engagement with popular culture products has also been a matter of debate in the academic literature. Fan-related pioneering research belongs to Henry Jenkins. With his book entitled Textual Poachers: Television Fans and Participatory Culture (1992), Jenkins has asked new questions about fans, in turn attempting to empower their position and changing the understanding of fan culture in academics. In his recent study, "Cultural Acupunture: Fan Activism and the Harry Potter Alliance" (2015), he observes the power that fans possessed in contemporary media culture. Matt Hills (2015) has also attributed a separate role to the key shifts in recent popular media culture, particularly elaborating "a move from the 'reactive audience'responding to media texts- to anticipatory, proactive fandoms who seek [further] information about new products" (Geraghty, 2015, p. 11).
} 
related Turkish websites (e.g. yeppudaa.com, asyadizileri.com, koredizileri.net). By means of these websites established by the fans, there has been an increase in fansubbed Korean dramas, and their popularity has even led to appropriated local productions in the Turkish drama sector. The more than thirty Turkish adaptations of Korean dramas ${ }^{4}$ in the last few years reveals the popularity of Korean dramas in Turkey.

As for the introduction of Korean cinema as options for Turkish consumers, it is possible to observe that, though Korean films have not been screened and not become regular fixtures in Turkish cinema, their fansubbed versions draw large viewers as soon as they are broadcast online. This Korean fan-induced popularity created through the Internet seems to influence the local cinema sector in Turkey, which has in turn initiated the production of film adaptations from Korea, such as Evim Sensin (2012), Sadece Sen (2014), and Senden Bana Kalan (2015). The popularity earned by Korean popular culture seems to have led the rediscovery of the Korean literature in Turkey as well. Though Korean literary works are receiving more attention from Turkish readers, and Turkish publishers have begun to introduce Korean works to Turkish readers, the support and the efforts required to introduce Korean literature in Turkey remain remarkably limited, compared to other Korean cultural products imported into the Turkish culture repertoire. Regarding the unfamiliarity of Korean literary pieces in Turkey, Sırrı Göksel Türközü provides the following explanation: non-recognition of Korean literature in Turkey may result from the fact that there is still no Korean writer awarded the Nobel Prize (Türközü, n.d.).

Although it is not the Turkish fans who introduce Korean literary pieces as options, their comments on Korean literature in numerous blogs, forums, and other fanpages, as well as their enthusiasm for Korean writers and books to be released seem to contribute to the increase in interest for Korean literature interest among Turkish readers. Furthermore, several Turkish fans of Korean popular culture have contributed to this interest through their own cultural production in literature. Inspired by the reallife experiences of the writer's herself, Didem Duygu Demir's Kore'deki Çatı Katımdan Sesleniyorum published by Ephesus Publishing in 2016 is a book written in Turkish featuring the love story of the characters Duygu and DongHo. Demir's contribution to the Turkish culture repertoire shows that fans do not simply consume Korean popular products, yet they also produce their own stories and novels.

Korean popular culture is sprawling among increasing numbers of Turkish fans of Korean Wave, who also appear to contribute the generation of more fans and popularity. Considering Even-Zohar's (1997) argument, it can thus be noted that, the agreement of Korean popular culture repertoire in Turkey is getting easier as the community which makes and uses given products becomes larger. This part of the study, on the one hand, has unveiled that the Turkish fans of Korean Wave contribute to the

\footnotetext{
${ }^{4}$ Some of the Turkish TV series adapted from or inspired by Korean dramas are as following: Beni Affet (2011), Emir'in Yolu (2012), Osmanlı Tokadı (2013), Bir Aşk Hikayesi (2013), Güneşi Beklerken (2013), Paramparça (2014), Kocamın Ailesi (2014), Günahkar (2014), Kiraz Mevsimi (2014), iliş̧i Durumu Karışık (2015), Aşk Yeniden (2015), Mayıs Kraliçesi (2015), Eve Dönüş (2015), Baba Candır (2015), Kiralık Aşk (2015), Çilek Kokusu (2015), Acı Aşk (2015), Maral: En Güzel Hikayem (2015), Hayat Şarkısı (2016), Aile İsi (2016), Tatıı Intikam (2016), Kış Güneşi (2016), Seviyor Sevmiyor (2016), Gülümse Yeter (2016), No: 309 (2016) and Yüksek Sosyete (2016).
} 
importation of various Korean popular culture products as options into the Turkish culture repertoire, and, on the other, it has outlined how the interaction among the Turkish fans, who act as cultural agents, triggers cultural production in other sites. By doing so, this study seeks to foreground the role online fan communities play in the cocreational practices regarding the production, translation, and distribution of media content. It also brings to the fore the fact that these cultural agents constitute "new transnational networks of media content producers and consumers" (Pérez-González, 2012 , p. 171) within the wider digital culture, which is more driven by "gradual advances in communication technology" (p. 168).

\section{Turkish Fandom of Korean Popular Culture}

As communications technology moves forward over the last two decades, the concept of "self-mediation" (Chouliaraki, 2010, p. 227) has gained prominence. Thus, "computermediated forms of production, distribution, and communication" (Manovich, 2001, p. 19) have turned into popular forms of sharing cultural practices and experiences. "The emergence of these fluid networks of mediation powered by advances in communication technology", as Luis Pérez-González points out, reflects broader changes "in the organization of social life and collective sites for interaction" (2014, p. 206). This participatory context of cultural production has blurred "the lines between between production and consumption, between making and using media, and between active or passive spectatorship of mediated culture" (Deuze, 2009, p. 148). Unlike their mass-media ancestors, collaborative technologies promote interactivity, hypertextuality and multimediality (Binark, 2007, p. 24). The impact of these technologies is distinctly evident in the involvement of ordinary people in the process of making media as cocreators of content.

Individuals, empowered with new technologies, have begun to exploit their right to participate within a given culture (Castells, 2000; Von Hippel, 2005; Hartley, 2009). These individuals as producers and consumers of the media content have taken significant roles in the circulation of media content (Jenkins, 2006b). The Internet has helped individuals to access media content and share their experiences and pleasures with others more easily. The conversations among people about the media they consume have made consumption a collective process -that's what French cybertheorist Pierre Lévy calls as "collective intelligence" (1997, p. 217). As Henry Jenkins (2006b) points out, "fans have moved from the invisible margins of popular culture into the center of current thinking about media production and consumption" (p. 12). Korean popular culture fans in Turkey, too, have taken advantage of new media technologies, which enabled them to extend the same media content through many different channels.

Translation studies have recently begun to address the emergence and consolidation of digital culture. As the concept of translation expands and translation practices diversify, the involvement of self-appointed agents in the process of media convergence seems to challenge "our understanding of translation agencies and the current organization of labour in the translation industry" (Pérez-González, 2012, p. 
163). In fact, a more collaborative model of translation had already appeared in the mid 1990s (Beninatto \& DePalma, 2008). However, self-appointed agents have recently been involved in digital media spaces. It turns out that audiovisual participatory translation as a flourishing form of cocreative labour has primarily been spurred by remarkable effects that connectivity and networked technologies have on the production of media content. Against the backdrop of the fast development of participatory translation, it can be suggested that non-professional collaborative practices would emphasize the centrality of translation to scholarship in the field of digital media studies (Pérez-González, 2012). In the present research, the participation of Turkish fans of Korean popular culture in the production, consumption and the dissemination of media content is identified as a productive strategy to stimulate active membership of digital media culture.

This growing influence of the socially networked Turkish fans has also become central to several translation research on fans in the Turkish context (Erguvan, 2016; Görgüler, 2016; Bogenç Demirel \& Görgüler, 2017; Duraner et al., 2017) ${ }^{5}$. In their research titled "Translation Training Emerging From New Sociabilities: Online Fan Communities and First Voices From The Field", Z. Emine Bogenç Demirel and Zeynep Görgüler (2017) underline that recent media technologies have had evolutionary effects on communicating patterns of individuals and online fan communities formed by means of social media facilitate new forms of production, consumption and distribution of media content. Demirel and Görgüler (2017) bring to the fore the generative potential of translation within the digital cultural industries. Similarly, the findings obtained by Jasmin E. Duraner, Gülfer Tunalı and Müge Işıklar Koçak (2017) also make translation more central to the agenda of digital media studies. Alongside these, in "Popularization through Translation in the New Media: The Case of Düşünbil”, Duygu Tekgül problematizes the role of translation in the popularization of scientific knowledge through digital media, revealing how digital media "bridg[e] the gap assumed between expert and lay and even challeng[e] the cultural authority of knowledge generated by institutions" (2018, p. 76). Perhaps the most common point that much research has indicated is the dialectic between digital culture and translation. In this light, for a deeper appreciation of Korean popular culture fandom in Turkey, this part of the paper intends to use and develop John Fiske's approach to fandom, which is based on "Bourdieu's metaphor of describing culture as an economy in which people invest and accumulate capital" (1992, p. 31).

This study has made use of the Internet to conduct asynchronous interviews as a methodology. A 34-question survey in electronic format (administered via Google Forms) was open for six months. This Internet-mediated interview, involving openended questions, was conducted with 43 Turkish fans, who are members of Korea-fans related websites, other Korean popular culture related Turkish websites, and several fan groups on Facebook. The questions aim at taking us deeper into their motivation for

\footnotetext{
${ }^{5}$ Among these, Duraner et al.'s research takes subtitling of the Korean dramas produced by fans as its focus of analysis and seeks out the agents involved in fansubbing in Turkey. The results of this research demonstrate that the translation traffic at the hands of fansubbers has started with Korean dramas and movies, and then it has opened a space for other products' -such as Korean pop music, Korean food- introduction into the Turkish culture repertoire as options.
} 
engaging with Korean cultural products, the social nature of media consumption from fans' point of view, and modes of reception which seems to be communal rather than individualistic.

The findings acquired from the e-mail interview conducted within the scope of this study reveal that Turkish fans of Korean popular culture are young, falling primarily within the age range between 15 and 38. This means that they are mostly made up of digital natives which refer to the new generation of young people born into the digital age and substantially influenced by the Internet and other modern information technologies (Prensky, 2001). However, it appears that Korean popular culture also attracts a relatively small group of Turkish fans, who can be considered digital immigrants, that is, individuals who usually have little appreciation for these new skills obtained and improved by digital natives through years of practice (Prensky, 2001). These results seem to correlate the Korean Embassy's survey (2011) of the Korea-Fans Internet community, in which $74.8 \%$ of fans are aged between 16 and 24 . In this research, high school and university students represent approximately $80 \%$ of those who enjoy Korean popular culture in Turkey. Out of 43 interviewees, only three participants are graduate students, two are working on a master's degree and one is studying for doctorate in the Department of Translation and Interpreting. Furthermore, most of the Turkish fans interviewed are women. The approximate ratios of the distribution of Turkish fans in terms of age, education, and gender ${ }^{6}$ provide overall information about the potential demand group of Korean popular culture in Turkey. The participants in this study reveal that they have been interested in and engaged with Korean popular culture related products and activities between six to ten years. Turkish fans who reported being actively engaged with Korean popular culture products only for several years constitute only a small fraction of this fan community. There are also some fans that sometimes stop following the latest developments on Korean popular culture and quit consuming its products. Therefore, it is possible to surmise that, considering many forms of participation and different levels of engagement, Turkish fans range from inexperienced fans, the irregular, and the expert in terms of the time they invest in this fandom.

The data obtained from the interviews regarding the quantity of products the interviewed fans have consumed so far confirm and complement the previous argument. The major fraction of Turkish fans attending this research reported watching twenty to sixty K-dramas and movies. This number exceeds a hundred for 12 out of 43 Turkish fans; one reported watching over two hundred dramas and six hundred movies. It seems evident that these fans substantially differ in terms of the effort and energy they invest in Korean Wave fandom, which may in turn influence their intimacy with their objects of attention. Furthermore, $\% 90$ of the Turkish fans noted that K-dramas

\footnotetext{
${ }^{6}$ Oh and Chae (2013) further investigates Turkish fans' distribution according to region in their study, in which the number of fans in the Marmara region (37.52) and the Central Anatolia (29.54) outnumbers the other regions, which implies Korean popular culture is influential in big cities such as İstanbul and Ankara (91).
} 
were their first encounter with Korean popular culture; only two fans reported first encountering Korean songs and one a Korean movie.

Another noticeable finding indicates the fact that as Korean dramas and movies earned significant popularity among Turkish fans, Korean literature and writers only made a small contribution to the growth of this fan community. Many participants in this research appear to be uninterested in Korean literature, be it popular or high. Among 43 participants, only more than half of them reported reading books from Korean literature, providing the titles of several books including both serious literature and popular culture. When asked for motives in reading Korean books, they reported following points: (i) their desire to invest this fandom with much more drive and dedication, (ii) their interest in building communication skills in Korean language, and (iii) their curiosity in bestseller and award-winning Korean books. Turkish fans were also asked how they discovered the book(s) they read. The answers to this question revealed the different mediums of access to Korean books: (i) their own search often via the Internet, (ii) suggestions from their friends or Korean teachers and (iii) their encounter on the websites of publishing houses. Furthermore, several fans reported finding the Turkish translations of Korean books at the library of the Korean Culture Center in Ankara. A noticeable amount of the fans interviewed complain about and express their regret at the limited availability of books translated from Korean into Turkish. Even in an unrelated question asking whether they post their comments and share their criticisms on the books they read, one female fan preferred restating her distress over the limited number of Korean books available in Turkey. The other fans who responded to this question reported sharing comments mostly through the Internet.

The responses obtained from Turkish fans demonstrate that most of the Turkish fans (close to 60\%) have begun their acquaintance with Korean popular culture products through the Internet, which is followed by friends, television, teacher and family respectively. In online platforms, fans post comments on different translated cultural products, and thus they use the opportunity to interact with other fans and exchange opinions on Korean products. They even hold online and offline meetings to share information about the recent activities and developments regarding these products. When the fans in this research were asked where they congregated with other fans, they listed a wide range of Korean fan and Korean popular related websites ${ }^{7}$ (korea-fans.com, yeppudaa.com, korezin.com, korefanatikleri.com, dongyul.com, Hallyusinnum.com, koredizileri.net, to name just a few), fan pages (Minoz Turkey, cnblue Turkey, Running Man-Turkey, Abnormal Summit Turkey), applications (K-pop Amino, K-drama Amino), and some other pages created by the Turkish fans in social networking sites of Instagram, Facebook and Twitter. An application, Kakaotalk, is also extensively used by the Turkish fans to share diverse content and information including photos, videos, and contact information. Several relatively more experienced Turkish fans added that before the boom of such websites in Turkey, they exploited some other websites (such as

\footnotetext{
${ }^{7}$ According to data about membership in Korea-fans and Yeppudaa, these websites have 65,933 (as of 2013)
} and 18,139 (as of 2016) members respectively. 
soompi.com, allkpop.com and onehallyu.com) as their primary sources of information about Korean popular culture.

The points that have been elaborated so far indicate that, establishing a fan community whose members interact with each other primarily via the Internet has provided a close and intense atmosphere of interaction among the Turkish fans of Korean popular culture. The following section of the study attempts to disclose that, the Turkish fans, who have both increased their visibility and expanded their influence over popular culture, appear to create a fan culture with a particular kind of habitus and their own forms of capital (e.g., popular cultural capital). The next part will take a critical look at the concept of "fandom", addressing the Korean fan community in Turkey and their construction of identity more closely.

\section{Turkish Fans from a Bourdieusian Perspective}

Fans can be defined as a group of people who "selects from the repertoire of massproduced and mass-distributed entertainment certain performers, narratives or genres and takes them into the culture of a self-selected fraction of the people" (Fiske, 1992, p. 30). Fandom is often linked with cultural forms such as romance novels and Hollywood stars, which the dominant/official value system discredits. However, as Janet Staiger (2000) points out, fandom cannot be easily classified into good and bad, and it is researcher's duty to provide adequate description and contemplated evaluation (p. 54). This part, drawing mainly on Bourdieu's work on the processes of cultural distinction, offers a way for investigating how fan status is built up and views any given fan culture not only as a community but also as a social hierarchy. This hierarchy stems from the Bourdieu's understanding that the behavior of an individual is conditioned by different kinds of "capital" (Bourdieu, 1984, p. 12).

According to Bourdieu, all social relations are economic, and people invest in knowledge, social networks, and culture (Hills, 2002). So, it is possible to observe an unequal distribution of these different kinds of capital in society. Seen from Bourdieu's point of view, the cultural system is first categorized in two groups: the first, official culture, which privileges certain cultural tastes often obtained through the educational system and other institutions such as galleries and museums; and the second, popular culture, which "receives no social legitimation or institutional support" (Hills, 2002, p. 31). While the top center of Bourdieu's map of cultural tastes includes the professions such as doctors, lawyers and other educated "tasteful" people, the bottom consists of those devoid of both economic and cultural capital, whom Bourdieu named "the proletariat". Bourdieu attaches the label of fandom to the latter rather than to the dominant bourgeoisie, noting that "working class tastes actually merit the debasement of the term 'fan' itself" (Hill, 2002, p. 21). According to Bourdieu, these individuals fail to possess social and cultural power, and thus they attempt to create a fandom for themselves as an illusory compensation (Bourdieu, 1984).

The findings gathered from the interviews with the Turkish fans reveal that, Bourdieu's consideration of proletarian culture as an undistinguished homogeneity 
partly fails to clarify the case of the Korean Wave fans in Turkey. Though the fan base appears to display similarities in terms of sex (largely female), age (largely midtwenties), and educational background (largely university students), their cultural preferences and interpretative practices seem to be diversified. Several Turkish fans in this research for instance invest deeply in Korean popular culture products and adopt cultural choices which are close to dominant aesthetic logic. Differing from those who contain their fandom exclusively in the context of several K-dramas or K-pop stars, these fans with a deep investment in their fandom use individual K-pop culture products as points of entry into a broader fan community and they attempt to construct an interrelated network composed of many movies, books, and other popular materials. Alongside the popular culture products in the movie industry, fashion, cosmetics and so on, these fans also reported being interested in traditional Korean music, technology in Korea, Korean politics, Korean history, historical destinations in Korea and Korean literature.

Though this is not to suggest that there is no discrimination between individuals who possess "high" cultural tastes preferred by dominant culture and those who rather enjoy popular aesthetics (Bourdieu, 1980), this research shows that, a small but sizeable fraction of Korean popular culture fans blurs those boundaries, treating these culture products as if they deserve the same degree of attention as so-called "high culture" products. It seems evident that Turkish fans share not simply a strong attachment to any given Korean popular culture product but a broader configuration of cultural interests. In this light, the following sub-sections point out that the Korean Wave fandom is formed of individuals from different walks of life, and that they vary in their engagement levels, cultural tastes, forms of participation and the type and degree of capital they possess.

\subsection{Accumulation of Popular Cultural Capital among the Turkish Fans}

Drawing on the Bourdieu's hierarchical perspective, Fiske coins the term "popular/unofficial cultural capital", accumulation of which is a major source of selfesteem among the fan community (1992, p. 33). For fans or others whose cultural tastes are often subordinated, popular cultural capital serves similar functions like "official" cultural capital for those in the dominant/official culture. As such, fans who accumulate the most cultural capital can gain prestige within the group and act as leaders. It is then possible to note that popular cultural capital, like economic capital, acts as a source of power. In relation to this point, when the Turkish fans are asked how to define the fan community that they are part of, they often emphasize the discrimination between those who are more educated, exert much more effort in this fandom, and possess high knowledge and the others who are deprived of such popular cultural capital. To sum up, considering that there may also emerge some struggles about the acquisition of cultural capital between and within communities and subculture, this research has made use of Fiske's (1992) term popular cultural capital, and thus related the circulation of cultural capital to popular culture products. So, it can be suggested that the concept of fandom is not independent from social hierarchy, a point also implied by Andrea MacDonald as following:

Fandom, just like the legitimate culture Bourdieu (1984) describes, is hierarchized... Fans do not explicitly recognize hierarchies [within their fan cultures; this is not always the 
case], and academics also hesitate to recognize hierarchies in fandom. Jenkins (1991, 1992), although never specifically denying the existence of hierarchies in fandom, does not address them, and implies that they do not exist by focusing on the grass roots production of fan culture (1998, p. 136).

Below are quotes ${ }^{8}$ from several Turkish fans commenting on this matter:

Fan 1: There is a huge difference between me and some high school girls in this (Korean popular culture) fandom. I don't share common interests and possess similar tastes with them. ${ }^{9}$

Fan 2: It is possible to make a distinction between those who are curious about K-pop culture on the surface only and those who move beyond it and are more deeply interested in Korean culture and its products. The former ones are like the Turkish youth who are engaged with cultural products only for pleasure. Their understanding of being a fan is something like fanaticism. They lack reasoning capability and often act foolish. When they are asked "what is culture?" they can only say "Korean women use Oppa to call older men such as their older brother" or "woow, Korean books have nice and colorful covers". However, I have also met with many other fans and several researchers, who really want to familiarize with the Korean culture, delving into its history, architecture, alternative medicine, herbal teas, beliefs (i.e. Buddhism) and spiritual practices, missionary activities, and Korean works of art. I like this kind of people and try to follow them in all platforms they appear.

Fan 3: ... some people engaged with this fandom may turn into prominent figures. This group generally consists of those who are more indulged and exert much effort in the fandom.

Fan 4: Those who share their criticisms about Korean books, movies, dramas, etc., in their personal blogs can easily get increasing number of followers. [...] These fans often make more meaningful comments on K-pop culture products. As a result, the more followers they get, the more significant and reliable the information they give becomes. Among these fans, some live in and others have been in Korea. [...] Furthermore, there is also a big difference between those who are recently interested in this fandom and those who have taken interest in K-pop products for ten to fifteen years.

Fan 5: Although most Turkish fans refuse to express it, there is a hierarchy among the fans. Therefore, some fans happen to be more prominent.

Fan 6: In forums such as yeppudaa, exchanging information among Turkish fans of K-pop culture moves beyond just posting comments on some K-dramas. For a deeper appreciation of any given drama or other K-pop culture products, fans often tend to explore Korean history and current issues on the Korean agenda. These fans do not confine themselves to the news they get from Turkish sources, yet they attempt to gather much more reliable information from foreign (mostly, Korean and English) sources. Such forums and fan pages turn into platforms full of individuals who act and work like professional reporters of culture and art activities. They try to inform others

\footnotetext{
${ }^{8}$ To give place to as many answers of the respondents as possible, I randomly selected an answer from each of the respondent for each matter discussed within the scope of this study. Undoubtedly, the respondents' answers given throughout the paper, which are deemed representative by the researcher, reflect the shared opinions of all the respondents.

${ }^{9}$ All translations are mine, unless otherwise stated.
} 
about daily issues in Korea, to introduce what their favorite stars or idols produce into the Turkish culture, to collect money so as to send gifts to some Korean celebrities, and more surprisingly they attempt to do charity works on behalf of them. At this point, I deem it necessary to note that this kind of Turkish fans are very rare.

From the perspective of dominant taste, fan interpretive practice is different from that preferred by the bourgeois culture not only in its choices of cultural products, but mostly in the ways that fans approach these products (Jenkins, 1992). In this view, fans are considered undisciplined and rogue consumers, who often reject the aesthetic distance that enable them to offer more elaborate interpretations. Jenkins further explains this Bourdieu-inspired approach to fan identity as following:

...fans seemingly blur the boundaries between the fact and fiction, speaking of character as if they have an existence apart from their textual manifestations, entering into the realm of the fiction as if it were a tangible place they can inhabit and explore. (p. 18)

In relation to this point, this research shows that a significant amount of the Turkish fans finds such commonly hold opinions irritating, which make them uncomfortable about speaking publicly as a fan or identifying with fan cultural practices. Perhaps due to the same reason, several Turkish fans attempted to justify their own preferences and pleasures as less inferior than those of others within the fan community. However, the comments of the Turkish fans interviewed seem to prove that the fans' interpretative practices contrast with the arguments above. As the following comments reveal, though Turkish fans display a strong emotional attachment to Korean popular culture products, their comments on those products (i.e., their reception) include very contradictory and criticizing points of view. They retain a distance between themselves (i.e., their fan identity) and the products they consume, and, contrary to expectations, they do not necessarily tend to integrate media representations into their daily life. It appears that each fan reevaluates his or her relationship to a given product, and then reconstructs its meaning according to his or her knowledge and understanding:

Fan 7: I often find the patriarchal nature of relationships in Korean dramas irritating and strange. In several dramas I watch, men take women by the hand and they forcibly take along women who are unwilling to do it. Many people take it as a romantic scene or act, which is not for me. I also have difficulty in making sense of why it is mostly the mother characters that follow the rules of their husbands and spend their whole time by sitting at home and cooking all day. I am personally against such gender stereotypes. While men characters in those dramas are generally wealthy, strong, and tough, women characters are oppositely poor, credulous, miserable, and unpresentable.

Fan 8: I discovered several Korean singers and famous bands while watching the two entertainment programs of Running Man and Infinite Challenge. But I don't really like them. [...] The bands I mentioned are usually formed of four to thirteen boys or girls, singing their songs full of English words and dancing in choreography. There are some agencies which set up a band and deliberately include one foreign member to it in order to help this band be popular in other countries as well. They launch licensed items including clothing (men's, women's, kid's), accessories, posters, notebooks, and many other products. So, it is possible to think of these bands as marketing projects. [...] Gathering beautiful girls and handsome guys together, these agencies provide the bands with stylish costumes and dancing lessons, and, regardless of whether their voice is good 
or not, they prepare and release singles and albums full of low-quality songs. The result is the circulation of so many tasteless and similar songs. As for Korean fashion, though I am not fond of but informed about it thanks to online shopping sites and applications. [...] I like men's satchels and rucksacks. I like the clothes designed for kids and infants as well. While baby wear is too colorful and densely patterned in Turkey, it is light-colored and plain.

Turkish fans also prove to be responsive to a primary medium of communication among their fan community, which is translation. Almost all know that translations are done from a pivot language (English) into Turkish. Regarding this, one participant stated that Japanese and Chinese were used as pivot languages by English fansubbers of Korean pop culture products, which makes easier to understand the dissatisfaction of some Turkish fans with the quality of translations. While most fans note that it is the poor translation in the English source which leads to problems in words choices and sentences fragments, as well as some ambiguities in the Turkish translations, several fans report that the voluntary nature of this translation practices has a negative effect on quality. Turkish fans are also aware of where the translations of Korean pop culture products are of higher/lower quality and rapidly released, as well as which voluntary translators produce higher quality of translations.

In this light, it is possible to conclude that the Korean fandom in Turkey cannot be confined to socially and culturally deprived individuals. Instead, the Turkish fan community consists of individuals who are steadily accumulating cultural capital (simply through their education) but wish to differentiate themselves by means of adopting different cultural tastes. As the findings suggest, there are a growing number of Turkish fans who possess substantial knowledge about the Korean cultural products, be they popular or not. They also have a critical stance towards the translations, through which most of them consume the Korean popular culture products. It also seems evident that there are more prominent fans within the community, and these fans are able to establish more credibility and broaden their reach to other fans by displaying their accumulated popular cultural capital (e.g. by their fansubbing practices or by writing a book targeting the Korean popular culture fans). At this juncture, it is significant to point out that several Turkish fans, who are supposed to possess a very high fan cultural capital, acquire high level of fan social capital as well. It is against this background that this paper confirms the Hills's argument against Bourdieu who "assumes the legitimacy of a fixed and monolithically legitimate 'cultural capital', rather than considering how 'cultural capital' may, at any single moment of culture-in-process, remain variously fragmented, internally consistent and struggled over" (2002, p. 22).

\subsection{Fan Social Capital}

Bourdieu's concept, social capital, briefly refers to membership in a group and thus it offers each of its members "with the backing of the collectivity-owned capital, 'a credential' which entitles them to credit, in the various senses of the word" (Bourdieu, 1986, p. 51). This concept is particularly useful for this study in that it lays much emphasis on the significance of the following points for the formation and persistence 
of fan community (i) the size of the network of connections in a specific group, (ii) the profits which stem from membership in a group, (iii) members' acting as a custodian of the limits of their group, (iv) the introduction of new members to the group and (v) the homogeneity of individuals in a certain group (pp. 52-53).

In the interviews, Turkish fans of the Korean Wave often refer to a sense of solidarity as a motive what supports and encourages them to be a part of this fandom. This confirms Jenkins's argument that "fan communities have long defined their memberships through affinities" (2006a, p. 137). When the Turkish fans are asked why they like the Korean culture and consume its cultural products, they frequently emphasize that their mutual passions and shared interests act as a powerful motivation for contributing the fandom where they learn how to establish an interaction that may soon penetrate every other aspect of their life. Among the most frequent answers given to the question of why they join various fan pages or K-pop related forums, (i) establishing social relations, (ii) gaining a sense of belonging, (iii) feeling a friendship and (iv) sympathizing with other fans are placed near the top. These fans mostly noted that it was pleasure to discover they were not alone. They also point to the fact that, belonging to this fan community is like talking the same language and that is what they need.

Most Turkish fans raised another common point in their responses. As the findings show, within the Korean popular fan community, there begins to develop an understanding that larger group of fans can do what even the most committed single fan cannot. Turkish fans think that if they create and revitalize social ties among themselves, then their community enlarges, and this fandom becomes a much more effective platform. The fans' responses reveal that, by forming new alliances with others and bringing to the foreground the activities they have been doing in the sidelines, they can do more than simply consuming Korean popular culture products:

Fan 9: The larger this fan community becomes, the more demand in K-pop products varies over time. As this fandom enlarges, famous K-pop singers and bands come to hold a concert in Turkey. It is also spreading into the Turkish cinema and television channels, in which the number of TV series and movies adapted from Korean dramas and movies, are rapidly growing. Also, it is now becoming easier to find some products such as Ramen, which are found nearly in every region in Korea. There are also Turkish tailors who are able sew traditional Korean clothes. This interest in K-pop culture has even spurred the growth of language centers offering Korean language lessons in Turkey.

Fan 10: It is surely beyond doubt that the increase in the number of Turkish fans matter much for the upsurge in every kind of Korean culture related activity. As more fans get together and contribute to this fandom, they can easily stir up the interest of more Korean products, singers, and popular bands.

It is possible to argue that the speed and frequency of communication has intensified the social bonds within the Korean fan community in Turkey. In this regard, Jenkins (2006a) notes the following: "Now fans may interact daily, if not hourly, online. Geographically isolated fans can feel much more connected to the fan community and home-ridden fans enjoy a new level of acceptance" (p. 142). In the case of Korean 
popular culture fans in Turkey, although the Internet has emerged as the most popular platform which provides communication opportunities for the Turkish fans, the interaction between these fans also occurs by means of various activities organized at schools, Korean Language Centers, Korean Culture Center in Ankara, as well as during meetings at Korean restaurants located in several big cities such as İstanbul and Ankara.

From the points we have discussed thus far, it appears that there is an increase in the size of network of connections within the Korean fan community in Turkey. According to many Turkish fans, the pleasure of being a member of Korean popular culture fandom comes largely from the sense of solidarity. Members of this fan community place no barrier in front of new fan participation; instead, they readily welcome newcomers. New members can easily join the fandom, but they often feel alienated from the expanding numbers of older and much committed fans, who "carry a large amount of intellectual capital around with them" (Jenkins, 2006a, p. 13). The latter group of fans consists of those who do more than consume these products, instead deeply investigate, and make meaning from materials others have characterized as trivial. A significant amount of the fans interviewed within the scope of this research reported that they felt obliged to contribute much more to this fandom to call themselves a Korean fan; otherwise, they felt like an outlier in this fan community. The last point given above seems to unearth that, although the Turkish fans of K-pop culture can widely be identified as a homogenous community, there is small but influential group of fans, who possess extensive information not only about Korean popular culture but also about the whole Korean culture and current issues, such as executive fans (i.e., founding members of the webpages on Korean popular culture), cultural consultants of Korean Cultural Center, as well as aca-fans ${ }^{10}$ (i.e., academic-fans). Turkish fans can thus be seen as a group of fans from, though largely homogenous, different walks of life coming together to share their fandom.

\subsection{Fan Habitus}

Jenkins argues that it is natural for fans to largely adopt similar cultural tastes about the products they are of interest because, as Bourdieu notes, "tastes are shaped by our earliest experiences" (as cited in Jenkins, 1992, p. 16) as members of a specific group. As he suggests, fans' practices are different from that preferred by bourgeois culture in many ways including their object choices (i.e., cultural products), the degree of their intensity, as well as the ways that they approach cultural products (1992, p. 18). For instance, seen through the perspective of dominant taste, fans seem to be frighteningly out of control consumers who "raid mass culture, claiming its materials for their own use, reworking them as the basis for their own cultural creations and social interactions" (p. 18). These points appear to claim that there is a kind of fan habitus consisting of people whose tastes are often dismissed as intellectually inferior. This kind

\footnotetext{
${ }^{10}$ It is beyond the scope of this paper to attempt delving into the nuances of the concept of aca-fans. This term briefly refers to those who involve in writing academically about fans and dealing with problems of asserting both "fan" and "academic" status.
} 
of habitus is also related to the internalization of a subservient behavior by the fans for a long time, which in turn engenders low social prestige for fans. Regarding the variability in fans' tastes and actions and the hierarchy even within the fan community, this deterministic view of fan habitus however contrasts with the case of the Turkish fans of Korean popular culture. The view that emerged from the findings of this research is more nuanced.

Though many Turkish fans note that others consider their mostly emotional engagement with the Korean popular culture products as worthless, they keep on endeavoring for their fan participation. As the findings discussed throughout the paper suggest, the increasing visibility and cultural centrality of the Turkish fans of Korean popular culture jointly influence the position of this community used to speaking from the margins. Particularly by means of the new digital environment, the speed of fan communication has increased, turning into, in Hills words, "just in time fandom" (2002, pp. 78-79). Increasingly keeping up with this environment, the Turkish fans go constantly online to search, connect, discuss, inform, and get informed about the rapidly proliferating developments in K-pop culture products and issues, which indicates the timeliness and responsiveness of the fans' devotion. As Jenkins summarizes:

...it is clear that new media technologies have profoundly altered the relations between media producers and consumers. [F]ans have gained greater visibility as they deployed the Web for community building, intellectual exchange, cultural distribution... (2006a, p. 150)

Then he continues as following:

The old rhetoric of opposition and cooperation assumed a world where consumers have little direct power to shape media content and where there were enormous barriers to entry into the marketplace, whereas the new digital environment expands their power to achieve, annotate, appropriate and recirculate media products... (p. 151).

An e-mail campaign has, for instance, given the Turkish fan community an opportunity of making their voice heard. Turkish fans sent a few e-mails to the broadcasters to broadcast K-pop music videos on their channels. In response to their efforts, since 2009, one of the leading music channels in Turkey, Number 1 , has begun to feature K-pop music videos of Korean idols such as DBSK, Super Junior, Bing Bang, and Girls Generation (Oh \& Chae, 2013, p. 92). Today, it is even possible to see the posters of these K-pop stars in the Turkish teen magazines, for instance, Trendy (p. 92). Another initiative indicating the increasing visibility of the Turkish fans of K-pop culture products is the airing of two television programs on December 7 and 28, 2016 by Kanal 7 (a Turkish nationwide TV channel) specifically for the K-pop culture fans in Turkey. In the programs named Izle 7 Kore Özel 1 and İle 7 Kore Özel 2 (lit. Watch Channel 7/Korean Exclusive 1 and 2), Turkish fans shared their experiences and pleasures with hundreds of thousands of people watching the program. They also discussed their preferences in Korean popular culture products ranging from dramas, fashion, cosmetics and foods to movies and songs. In another program Söz Müzik (lit. Lyrics and Melody), executives of Kanal 7 reported to show regard to the interest in Korean dramas among the Turkish fans of 
Korean Wave, adding that they would likely include several Korean dramas into the broadcast stream in the next season.

Considering these points, one can plausibly conclude that, collaborating their common interests, Turkish fans have begun to directly access the means of commercial cultural productions (e.g. in television channels) and in turn influence entertainment industry decisions. It seems that Turkish fans of Korean Wave can no longer be considered acting from a position of social weakness. Though there is almost no room for divergence in fans' actions since they are expected to act in uniform ways that enjoy social approval in a dominant value system, this point does not apply to the case of Turkish fans. Furthermore, as it is discussed throughout the paper, Turkish fans are often highly educated people who can do more than spending their time constructing detailed interpretations of Korean dramas or some other culture products. Therefore, isolating Turkish fans of Korean popular culture from others, marginalizing their fan activities and subordinating their cultural tastes can only lead to a fixed model neglecting the fractions within this fan community and overlooking their practices and contributions which seems to enrich the Turkish culture repertoire.

\section{Conclusion}

The Korean Wave has noticeably picked up momentum and transformed South Korea into one of the key centers in the production of transnational pop culture, exporting various cultural products to a few countries including Turkey. Korean fans in Turkey seem to assert their authority as consumers of Korean culture products and began to assume the role of self-appointed and voluntary cultural agents, who are involved with thinking about and providing new options without being commissioned by anyone. Examining Turkish fan community as a cultural and social entity, this study has set out to explore with critical empathy the particularities of this fandom, which is a complex and fluid by nature, inviting different forms of participation, practices, and experiences. This examination in turn calls special attention to the involvement of non-professional translators and other self-appointed agents in the coproduction and circulation of media content in the era of digital culture and reveals the implications of their cocreational practices for the consolidation of digital culture.

First, this study has disclosed that, cultural capital is not a single, set entity that exists in a given culture; instead, the concept of cultural capital may vary between communities and subcultures. As the findings obtained from the interviews suggest, the accumulation of popular cultural capital can for example create an opportunity for Turkish fans of Korean popular culture to gain prestige within the fan community, which indicates socially hierarchical structuring of the fandom. Furthermore, against the argument that fans are often not able to abide by the aesthetic distance that enable them to offer more contemplated evaluations about their objects of attention, the fans' interpretative practices in the present study have revealed that Turkish fans may offer elaborate interpretations about the Korean popular culture products and take a very critical stance vis-à-vis these products, holding off their emotional attachment. 
It has also appeared that the accumulation of social capital means a lot more than that of cultural capital for the Korean fan community in Turkey. Maintenance, visibility, and cultural centrality of this fan community all hinge upon establishing more extensive social relations, which implies that larger group of fans can do what even the most devoted and knowledgeable single fan capital cannot. The interviewed Turkish fans have been found to be putting much emphasis on revitalizing social ties among themselves, which may in turn enlarge their fan community and increase the cultural productions, practices, and activities regarding the Korean popular culture.

The results of this research have also indicated that, an increasing number of Turkish fans have begun to contribute to the boom of Korean popular culture in Turkey through their fansubbing activities and their own cultural production. These practices have on the one hand provided them with accumulated popular cultural capital, and, on the other, enhanced the visibility and influence of the Korean fan community over popular culture. As a result, a deterministic view of fan habitus which is based on an understanding that fans' objects of attention are trivial, and fans' cultural tastes can be subordinated has been found to be in contrast with the case of Korean popular culture fans in Turkey, who markedly vary in the forms and degrees of participation in their fandom. Instead of speaking from margins, members of the Korean popular culture fan community in Turkey are recently encouraged by the new media environment which allows for freer flows of ideas and content.

Finally, it can be noted that there is much scope for further research on the translated popular products and practices. This study attempts to invite researchers into translation, who largely tend to avoid problematizing these products, to reconsider Stuart Hall's (1981) argument that popular culture "is neither wholly corrupt [n]or wholly authentic" but rather "deeply contradictory," characterized by "the double movement of containment and resistance, which is always inevitably inside it" (228). It is also expected that this research will stimulate further research on the dialectic between translation and digital culture.

\section{References}

Beninatto, R. S. \& DePalma, D. A. (2008). Collaborative translation. Multilingual Resource Directory Editorial Index 2007, 49-51.

Binark, M. (2007). Yeni medya çalışmalarında yeni sorular ve yöntem sorunu. In M. Binark (Ed.), Yeni medya çalışmaları (pp. 21-44). Dipnot Yayınları.

Binark, M. (2019). Kültürel diplomasi ve Kore dalgası "Hallyu": Güney Kore'de sinema endüstrisi, K-Dramalar ve K-Pop. Siyasal Kitabevi.

Bogenç Demirel, Z. E. \& Görgüler, Z. (2017). Yeni toplumsallıklar etrafında yükselen çeviri eğitimi: Çevrimiçi fan toplulukları ve sahadan ilk sesler. Hacettepe Üniversitesi Frankofoni Dergisi, 30, 303-315.

Bourdieu, P. (1980). The aristocracy of culture (R. Nice, Trans.). Media, Culture, and Society, 2, 225-254. 
Bourdieu, P. (1984). Distinction: A social critique of the judgement of taste (R. Nice, Trans.). Routledge.

Bourdieu, P. (1986). The forms of capital (R. Nice, Trans.). In J. Richardson (Ed.), Handbook of Theory and Research for the Sociology of Education (pp. 241-258). Greenwood.

Castells, M. (2000). The information age, volume 1: The rise of the network society (2nd ed.). Blackwell.

Chesterman, A. (2006). Questions in the sociology of translation. In J. F. Duarte, A. A. Rosa \& T. Seruya (Eds.), Translation studies at the interface of disciplines (pp. 9-27). John Benjamins.

Chouliaraki, L. (2010). Self-mediation: New media and citizenship. Critical Discourse Studies, 7(4), 227-232.

Deuze, M. (2009). Convergence culture and media work, In J. Holt \& A. Perren (Eds), Media industries: History, theory, and method (pp. 144-156). Wiley-Blackwell.

Duraner, J., Işıklar-Koçak, M. \& Tunalı, G. (2017). Fansubbers as cultural agents for Korean dramas, In D. Orrego-Carmona \& Y. Lee (Eds.), Non-professional subtitling (pp. 145-170). Cambridge Scholars Publishing.

Erguvan, M. (2016). Venutian scale in the realm of subtitling in Turkey: A comparative analysis of the fansubs and the official subtitles of Family Guy. Çeviribilim ve Uygulamaları Dergisi, 22, 147-168.

Even-Zohar, I. (1997). Factors and dependencies in culture: A revised draft for polysytem culture research. Canadian Review of Comparative Literature / Revue Canadienne de Littérature Comparée, XXIV(1), 15-34.

Even-Zohar, I. (2002). The making of culture repertoire and the role of transfer. In S. Paker (Ed.), Translations: (Re)Shaping of literature and culture (pp. 166-174). Boğaziçi University Press.

Even-Zohar, I. (2005). Idea-makers, culture entrepreneurs, makers of life images, and the prospects of success. Papers in Culture Research, 184-202. http://www.tau.ac.il/ itamarez/works/books/EZ-CR-2005.pdf.

Fiske, J. (1992). The cultural economy of fandom. In L. A. Lewis (Ed.), Adoring audience: Fan culture and popular media (pp. 30-49). Routledge.

Geraghty, L. (Ed.) (2015). Popular media cultures: Fans audiences and paratexts. Palgrave Macmillan.

Görgüler, Z. (2016). Yeni toplumsallıklar etrafında yükselen çeviri pratikleri: Türkiye'de tara-çeviri (Manga) içeriklerinin dolaşımı ve netnografik çözümlemeler [Unpublished doctoral dissertation]. Yıldız Teknik Üniversitesi.

Hartley, J. (2009). From the consciousness industry to the creative industries: Consumer-created content, social network markets, and the growth of knowledge, In J. Holt \& A. Perren (Eds.) Media industries: History, theory, and method (pp. 231-244). Wiley-Blackwell.

Hills, M. (2002). Fan cultures. Routledge.

Jenkins, H. (1992). Textual poachers: Television fans and participatory culture. Routledge. 
Jenkins, H. (2006a). Fans, bloggers and gamers: Exploring participatory culture. New York University Press.

Jenkins, H. (2006b). Convergence culture: Where old and new media collide. New York University Press.

Korean Embassy report. (2011). Survey on the Korea image in Turkey.

Lévy, P. (1997). Collective intelligence: Mankind's emerging world in cyberspace. Perseus.

MacDonald, A. (1998). Uncertain utopia: science fiction media fandom and computer mediated communication. In Harris, C. \& Alexander, A. (Eds), Theorizing fandom: Fans, subculture and identity (pp. 131-152). Hampton Press.

Manovich, L. (2001). The language of new media. MIT Press.

Oh, C.-J. \& Chae, Y.-G. (2013). Constructing culturally proximate spaces through social network services: The case of Hallyu (Korean Wave) in Turkey. Uluslararası Ilişkiler, 10(38).

Pérez-González, L. (2012). Amateur subtitling as immaterial labour in digital media culture: An emerging paradigm of civic engagement. Convergence: The International Journal of Research into New Media Technologies, 19(2), 157-175

Pérez-González, L. (2014). Translation and new(s) media: Participatory subtitling practices in networked mediascapes. In J. House (Ed.), Translation: A multidisciplinary approach (pp. 200221). Palgrave Macmillan.

Prensky, M. (2001). Digital natives, digital immigrants, part II: Do they think really differently. On the horizon, 9(6), 1-9.

Staiger, J. (2000). Perverse spectators: The practices of film reception. New York University Press.

Tekgül, D. (2018). Popularization through translation in the new media: The case of Düşünbil. Çeviribilim ve Uygulamaları Dergisi, 22, 71-86.

The Korean wave: A new pop culture phenomenon. (2011). Korean Culture and Information Service Ministry of Culture, Sports and Tourism. https://www.korea.net/Resources/Publications/About-Korea/view?articleld=2215\#

Türközü, S. G. (n.d.). Türk-Kore edebiyatları arasındaki farkındalık ve birbirini tanıma [Unpublished manuscript]. Erciyes University, Kayseri, Turkey. https://www.academia.edu/4451223/Kore Turk Edebiyati farkindalik. 1-5.

Von Hippel E. (2005). Democratizing innovation. MIT Press.

Wolf, M. (2007). Introduction, In. M. Wolf \& A. Fukari (Eds.), Constructing a sociology of translation (pp. 1-36). John Benjamins Publishing Company.

Wolf, M. \& Fukari, A. (2011). Mapping the field: Sociological perspectives on translation. International Journal of the Sociology of Language, 207, 1-28. 


\section{Appendix}

\section{Increasing Visibility of the Turkish Fans of South Korean Popular Culture through Translation}

This is a research study.

The aim of the study is to broadly describe the characteristics of the fans, who are intimately interested in South Korean popular culture, especially through new media and various social media applications in Turkey. People who play a role as a content producer, consumer or distributor in the production and dissemination process of cultural contents, known as Korean Wave ("Hallyu") acting as a cultural diplomacy tool and channel, can participate in the study.

Participation in this study poses no foreseeable risks.

Your participation in this study is completely voluntary and you may refuse to participate or leave the study at any time.

You will incur no costs from participating in this study. You will not be compensated for participating in this study.

No personal information is required from you. Records identifying participants will be kept confidential to the extent permitted by applicable laws and regulations and will not be made publicly available.

When you complete this questionnaire and click on Send Form, it will be considered that you consented to participate in the study.

For further information about this study, please contact Mehmet Erguvan through e-mail atm.erguvann@gmail.com.

Thank you very much in advance for your participation and support.

Mehmet Erguvan, PhD.

1) Your age, gender, and education level.

2) When did you first encounter South Korean culture?

3) What was the first cultural product (TV series, movies, books, fashion products, etc.) you encountered?

4) How many Korean dramas/movies have you watched or how many Korean books have you read so far? If you remember, also write their titles.

5) How did you first encounter this cultural product?

6) What makes you be fond of Korean culture? Why do you watch, read, or use the products of this culture?

7) Do the cultural elements (traditions, values, etc.) in Korean dramas/films/books seem familiar to you? Do you find it difficult to understand these elements? If so, how do you tackle with this situation?

8) What do you follow or know about Korean culture other than TV series/movies/books? Do you know anything about Korean songs or sense of fashion? 
9) Do you follow other cultures in the Far East? Have you watched and read any product (TV series/film etc.) belonging to those cultures?

10) Are there platforms where those who follow Korean cultural products discuss these products among themselves? On which platforms are these products discussed? Forums, Facebook "fan" pages, etc.

11) Are you a member of any platform about Korean culture? If yes, how long have you been a member?

12) Why did you join such a platform?

13) How do you feel about coming together with people who have the same tastes as you about Korean culture?

14) Do you think you have created a separate community (fan-community) that follows, consumes, and criticizes Korean cultural products? If yes, how would you describe this community?

15) What does being part of a fan community mean to you?

16) What do the people around you think about your interest in Korean cultural products? If those who follow Korean cultural products are a separate "fan community", how does this community get reactions from the outside?

17) What are the requirements for joining this community? Can anyone join Korean fan groups? Are there prominent actors/persons among Korean drama/movie fans?

18) What do you think about the increasing number of Korean culture fans?

19) What do Korean culture fans discuss and talk about on various platforms?

20) Where else do you communicate with the "Korean culture fans" you encounter in the forums, apart from electronic media?

21) In which language do you follow Korean dramas, movies, books, etc.?

22) If you follow the products through their Turkish translations, do you find these translations sufficient (good)? If not, explain why. Do you report any translations you find "inadequate" to anyone?

23) How do you contribute to the consumption process of Korean products in Turkey?

24) Do you find the translators involved in this process successful?

25) Do you speak Korean? If you do not, did your interest in Korean culture push you to learn Korean?

26) What genre of books do you usually read? (Thriller, romance, horror, etc.)

27) Have you read a Korean book? If yes, which authors and books have you read? 
28) Did you like the books you read? What did you like most? Is there anything you did not like?

29) What prompted you to read this book or books?

30) Were these books translated or indigenous products?

31) The Korean novel The Secret Garden, which was then translated into Turkish, was adapted from a Korean TV series. What do you think about this adaptation and its Turkish translation? Would you like to consume new TV show adaptations?

32) How did you discover the Korean books you read?

33) Did you find the translation of these books sufficient/good? Do you know their translators? While purchasing or reading any translated book, do you pay attention to the book's cover design, the translator's notes, and the use of language in translations?

34) Do you share your comments about the books you read on social media or anywhere else?

\section{Görünürlüğü \\ Güney Kore Popüler Kültürünün Türkiye'deki Fanlarının Çeviri Yoluyla Artan}

Bu bir bilimsel araştırma çalışmasıdır.

Bu çalışmanın amacı Türkiye'de bilhassa yeni medya ortamları ve çeşitli sosyal medya uygulamaları vasıtasıyla Güney Kore popüler kültürüyle yakından ilgilenen hayran kitlesinin sahip olduğu nitelikleri genel hatlarıyla betimlemektir. Çalışmaya Kore Dalgası ("Hallyu”) olarak bilinen kültürel içeriklerin kültürel diplomasi aracı ve kanalı olarak devlet politikasıyla üretim ve yayılım sürecinde içerik üreticisi, tüketici veya dağıtıcı olarak rol oynayan, bir diğer deyişle, bir şekilde içeriklerin pekiştirilmesinde ve yeniden üretilmesinde etkin olan kişiler katılabilmektedir.

Ankete katılmanın öngörülebilen hiçbir riski bulunmamaktadır. Ankete katılım tamamen gönüllülük temelindedir ve katılım karşılı̆ında herhangi bir ödeme ya da ödüllendirme yapılmayacaktır.

Anket soruları sizden özel bilgiler talep etmemektedir. Sorulara vereceğiniz yanıtlar sadece araştırmacı tarafından görüntülenecek ve analiz edilecektir. Her türlü kişisel bilgi yüksek güvenlikli, şifreyle korunan bilgisayarlarda muhafaza edilecektir.

Anketi tamamlayıp "Formu Gönder" tuşuna tıklayarak bu çalışmaya gönüllü olarak katıldığınızı Kabul etmiş sayılıyorsunuz.

Anketle ilgili her türlü sorularınızı Arş. Gör. Dr. Mehmet Erguvan'a m.erguvann@gmail.com adresinden e-posta göndererek sorabilirsiniz.

Katılımınız ve desteğiniz için şimdiden teşekkür ederiz.

Arş. Gör. Dr. Mehmet Erguvan

1) Yaşınız, cinsiyetiniz ve eğitim bilgileriniz.

2) Güney Kore kültürüyle ilk kez ne zaman karşılaştınız? 
3) Karşılaştığınız ilk kültürel ürün (dizi, film, kitap, moda vs.) hangisiydi?

4) Bugüne kadar ortalama kaç Kore dizisi/filmi izlediniz ya da kitaplarından kaç tane okudunuz? Hatırlıyorsanız dizinin/filmin/kitabın adını da yazınız.

5) Bu kültürel ürünle ilk karşılaşmanız hangi vasıtayla (TV, internet, arkadaş, aile) gerçekleşti?

6) Size Kore kültürünü sevdiren nedir? Neden bu kültüre ait ürünleri izliyor, okuyor ya da kullanıyorsunuz?

7) Kore dizi/film/kitaplarındaki kültürel unsurlar (gelenekler, değer yargıları vs.) size yakın geliyor mu? Bu unsurları anlamak sizi zorluyor mu? Zorluyorsa, bu durumda neler yapıyorsunuz?

8) Dizi/film/kitap dışında Kore kültürüyle ilgili takip ettiğiniz ya da bildiğiniz neler var? Örneğin, şarkıları ya da modası hakkında bir bilginiz var mı?

9) Uzak Doğu'daki diğer ülkelerin kültürünü takip ediyor musunuz? O kültürlere ait bir ürünü (dizi/film vs.) izleyip okudunuz mu?

10) Kore'ye ait kültürel ürünleri takip edenlerin bu ürünleri kendi aralarında tartıştığı platformlar var mı? Bu ürünler hangi platformlarda tartışılıyor? Forumlar, Facebook "fan" sayfaları vs.

11) Siz de Kore kültürüyle ilgili bir forum ya da başka bir platforma üye misiniz? Üye iseniz, kaç yıldır üyesiniz?

12) Böyle bir platforma üye olma sebebiniz neydi?

13) Çeşitli ortamlarda Kore kültürüyle ilgili sizinle aynı beğenileri olan kişilerle görüşmek sizde nasıl bir his uyandırıyor? Size ne(ler) kazandırıyor?

14) Kore'ye ait kültürel ürünleri takip eden, tüketen, eleştiren ayrı bir kitle ("fan" -hayrantopluluğu) oluşturduğunuzu düşünüyor musunuz? Yanıtınız evet ise, bu topluluğu nasıl tanımlarsınız?

15) Bir hayran topluluğunda bulunmanın sizin için anlamı nedir?

16) Kore'ye ait kültürel ürünleri takip etmeniz etrafınızda nasıl karşılanıyor? Eğer Kore'ye ait kültürel ürünleri takip edenler ayrı bir "fan topluluğu" ise, bu topluluk dışarıdan nasıl tepki topluyor?

17) Bu topluluğa girmenin şartları nedir? Herkes Kore fan grubuna dahil olabilir mi? Kore dizi/film hayranları arasında öne çıkan kişi ya da kişiler oluyor mu?

18) Kore kültürünü sevenlerin sayısının artması "Kore kültürü hayranları" için ne gibi bir önem taşıyor? 
19) Kore kültürü hayranları çeşitli platformlarda neleri tartışıyor, nelerden bahsediyor?

20) Forumlarda iletişim kurduğunuz "Kore kültürü hayranlarıyla" elektronik ortamlar dışında nerelerde iletişim kuruyorsunuz?

21) Kore kültürüne ait dizileri, filmleri, kitapları vs. hangi dilden takip ediyorsunuz?

22) Ürünleri Türkçe çevirileri sayesinde takip ediyorsanız, bu çevirileri yeterli (iyi) buluyor musunuz? Bulmuyorsanız sebebini açıklayınız. "Yetersiz" bulduğunuz çevirileri herhangi birine bildiriyor musunuz?

23) Kore kültürüne ait ürünlerin Türkiye'de tüketilmesi sürecine ne gibi bir katkıda bulunuyorsunuz? (Altyazı hazırlamak, ürünleri sosyal medyada paylaşıp reklamını yapmak gibi)

24) Bu süreçte yer alan çevirmenleri başarılı buluyor musunuz?

25) Korece biliyor musunuz? Bilmiyorsanız, Kore kültürüne merakınız sizi Korece öğrenmeye itti mi?

26) Genel olarak hangi tür kitaplar okursunuz? (Polisiye, aşk romanı, korku romanı vs.)

27) Kore edebiyatına ait bir kitap okudunuz mu? Okuduysanız hangi yazar ve kitaplarını okudunuz?

28) Okuduğunuz kitapları beğendiniz mi? En çok ne hoşunuza gitti? Beğenmediğiniz/hoşlanmadığınız herhangi bir şey oldu mu?

29) Sizi bu kitap ya da kitapları okumaya iten neydi?

30) Okuduğunuz kitaplar çeviri miydi?

31) Kore'den gelip Türk edebiyatında okurlarla buluşan Gizli Bahçe adlı roman Korece bir diziden uyarlandı. Bu uyarlama ve Türkçe çevirisi hakkında ne düşünüyorsunuz? Diziden kitaba uyarlamaların devamının gelmesini ister misiniz?

32) Kore edebiyatından okuduğunuz kitapları nasıl keşfettiniz?

33) Bu kitapların çevirisini beğendiniz mi? Çevirmenlerini tanıyor musunuz? Kitabı satın alırken ya da okurken kapak tasarımına, (varsa) çevirmenin notlarına, çevirmenin kullandığı dile vs. dikkat eder misiniz?

34) Okuduğunuz kitaplarla ilgili yorumlarınızı sosyal medyada ya da başka herhangi bir yerde paylaşıyor musunuz? 